University of Nebraska - Lincoln

DigitalCommons@University of Nebraska - Lincoln

\title{
The effect of row spacing and seeding rate on biomass production and plant stand characteristics of non-irrigated photoperiod-sensitive sorghum (Sorghum bicolor (L.) Moench)
}

John L. Snider

USDA, john.snider@ars.usda.gov

Randy L. Raper

USDA

Eric B. Schwab

USDA

Follow this and additional works at: https://digitalcommons.unl.edu/usdaarsfacpub

Part of the Agricultural Science Commons

Snider, John L.; Raper, Randy L.; and Schwab, Eric B., "The effect of row spacing and seeding rate on biomass production and plant stand characteristics of non-irrigated photoperiod-sensitive sorghum (Sorghum bicolor (L.) Moench)" (2012). Publications from USDA-ARS / UNL Faculty. 876.

https://digitalcommons.unl.edu/usdaarsfacpub/876

This Article is brought to you for free and open access by the U.S. Department of Agriculture: Agricultural Research Service, Lincoln, Nebraska at DigitalCommons@University of Nebraska - Lincoln. It has been accepted for inclusion in Publications from USDA-ARS / UNL Faculty by an authorized administrator of DigitalCommons@University of Nebraska - Lincoln. 


\title{
The effect of row spacing and seeding rate on biomass production and plant stand characteristics of non-irrigated photoperiod-sensitive sorghum (Sorghum bicolor (L.) Moench)
}

\author{
John L. Snider ${ }^{\mathrm{a}, *}$, Randy L. Raper ${ }^{\mathrm{a}}$, Eric B. Schwab ${ }^{\mathrm{b}}$ \\ a USDA, Agricultural Research Service, Dale Bumpers Small Farms Research Center, 6883 South State Hwy 23, Booneville, AR, 72927, USA \\ ${ }^{b}$ USDA, Natural Resources Conservation Service, 3381 Skyway Drive, Auburn, AL, 36830-6443, USA
}

\section{A R T I C L E I N F O}

\section{Article history:}

Received 2 June 2011

Received in revised form 27 July 2011

Accepted 27 July 2011

Available online 16 August 2011

\section{Keywords:}

Bioenergy

Photoperiod-sensitive sorghum

Row spacing

Seeding rate

Plant population

Biomass

\begin{abstract}
A B S T R A C T
To evaluate row spacing and seeding rate effects on yield and plant stand characteristics of high-biomass sorghum, a photoperiod-sensitive cultivar was sown at three different row spacings $(76,38$, and $19 \mathrm{~cm})$ and seeding rates $\left(218,000,306,000\right.$, and 393,000 seeds ha ${ }^{-1}$ for one site-year and $116,000,204,000$, and 291,000 seeds ha $^{-1}$ for three site-years) from 2009 to 2010 in Alabama and Arkansas, USA. Measurements included above-ground dry matter production, plant height, stem density, and stem diameter. Narrower row spacing (i.e. $19 \mathrm{~cm}$ ) produced the highest biomass for all site-years. Increasing seeding rate did not affect yield for three of the site-years, and decreased yield for one. The $19 \mathrm{~cm}$ row spacing produced the highest stem densities. Plant height increased with increasing seeding rates at one site and decreased with higher seeding rates at another site. At one location, stem diameter declined as seeding rates and stem density increased. It was concluded that narrower row spacing $(19 \mathrm{~cm})$ provides the maximum yield benefit by significantly increasing stem density, and low seeding rates $\left(116,000\right.$ seeds $\left.^{-1}\right)$ are preferable because higher seeding rates do not positively affect yield and may cause morphological changes (i.e. taller plants with thinner stems) conducive to lodging.
\end{abstract}

Published by Elsevier B.V.

\section{Introduction}

The Energy Independence and Security Act of 2007 is intended to lessen U.S. dependence on non-renewable fossil fuel energy sources and requires increased production of alternative fuels to 36 billion gallons by 2022. Because Congress has capped the production of corn-based ethanol production at 15 billion gallons, the remainder of the 36 billion gallons will be comprised of advanced biofuels derived largely from lignocellulosic feedstock sources (Service, 2010). Lignocellulosic bioethanol production has become an attractive alternative to using non-structural carbohydrate (starch and soluble sugars) sources for ethanol production (Sivakumar et al., 2010; Waltz, 2008) because the cellulosic components of plant cell walls represent an abundant feedstock for bioenergy conversion (Sivakumar et al., 2010) and because biofuels can be produced from non-food sources such as corn stover, various grasses, and woody biomass without competing with the production of important food crops (Sivakumar et al., 2010; Waltz, 2008). As a result, a number of crops have been studied for their potential use as dedicated bioenergy feedstock, including grasses such as Miscanthus (Fischer

\footnotetext{
* Corresponding author. Tel.: +1 479675 3834x342; fax: +1 4796752940.

E-mail address: john.snider@ars.usda.gov (J.L. Snider).
}

et al., 2005), sorghum (Rooney et al., 2007; Venuto and Kindiger, 2008; Wang et al., 2008), and switchgrass (Schmer et al., 2008) and short-rotation woody species such as willow and poplar (Fischer et al., 2005; Aylott et al., 2008; Stolarski et al., 2011).

Sorghum has a number of characteristics making it a promising dedicated biofuel feedstock source, including high productivity (Amaducci et al., 2000; Habyarimana et al., 2004; Rooney et al., 2007), drought tolerance (Amaducci et al., 2000; Rooney et al., 2007), and substantial potential for genetic improvement (Carpita and McCann, 2008; Rooney et al., 2007). Although the amount of starch and soluble carbohydrates produced per unit land area are important for ethanol production from grain and sweet sorghum, respectively, cellulosic ethanol production from high-biomass sorghum requires that the total amount of cellulosic biomass per unit land area be maximized (Rooney et al., 2007; Carpita and McCann, 2008).

A number of studies have evaluated the impact of practical management decisions (i.e. fertilization requirements, row spacing, plant population) on sweet sorghum (Martin and Kelleher, 1984), grain sorghum (Welch et al., 1966; Steiner, 1986), and forage sorghum productivity (Marsalis et al., 2010). Management strategies are well-defined for optimal syrup (Mask and Morris, 1991), grain (Mask et al., 1988), and forage production (Ball, 1998). Recently, Wortmann et al. (2010) showed that bioethanol 
production from sweet sorghum in Nebraska responded positively to increased $\mathrm{N}$ fertilizer application rates (up to $80 \mathrm{~kg} \mathrm{~N} \mathrm{ha}^{-1}$ ) and plant population (up to 175,000 plants ha $^{-1}$ ) for one of three cultivars evaluated, whereas ethanol yields for the other two cultivars were unaffected by fertilizer application and plant population.

Photoperiod-sensitive sorghum varieties are capable of achieving high levels of biomass production by continuing vegetative growth throughout the season. These varieties do not flower under the day lengths observed during typical southern U.S. growing seasons (Rooney et al., 2007; Venuto and Kindiger, 2008). When compared with sweet and grain sorghum, comparably little information is available on management practices for the production of high-biomass sorghum varieties for bioenergy purposes. For example, Habyarimana et al. (2004) reported that increasing plant densities from 100,000 to 200,000 plants ha $^{-1}$ resulted in higher above-ground yield at only one of three locations in Italy. Venuto and Kindiger (2008) recently reported that a single late-season harvest was superior to two harvests for yield of a number of hybrid forage sorghum and sorghum-sudangrass hybrids (including photoperiod-sensitive genotypes) in central Oklahoma. However, information on the impact of basic agronomic practices such as row spacing and seeding rate on biomass production in photoperiod-sensitive sorghum is limited for the southern U.S. Because photoperiod sensitive sorghum would be harvested for cellulosic biomass rather than for grain, soluble sugars, or as a nutritional source for cattle, row spacing and seeding rates that maximize total above-ground biomass may be different that those utilized for optimal grain, sugar, and forage production. Consequently, the objectives of this research were (1) to measure the effect of row spacing and seeding rate on the yield of a photoperiodsensitive sorghum cultivar (Sorghum Partners ${ }^{\circledR} 1990$ ) and (2) to quantify the effects of row spacing and seeding rate on plant height, stem density, and stem diameter of this cultivar.

\section{Materials and methods}

\subsection{Study locations and general crop management practices}

A total of four site-years were utilized for the current study. In April 2009, plots $3.0 \mathrm{~m}$ wide by $9.1 \mathrm{~m}$ long were established at E.V. Smith Research Station (EVS 2009), Shorter, AL (85 $53^{\prime} 50^{\prime \prime} \mathrm{W}$, $32^{\circ} 25^{\prime} 22^{\prime \prime} \mathrm{N}$ ) and at the Gulf Coast Experiment Station (Fairhope 2009), Fairhope, $\mathrm{AL}\left(87^{\circ} 52^{\prime} 55^{\prime \prime} \mathrm{W}, 30^{\circ} 32^{\prime} 56^{\prime \prime} \mathrm{N}\right)$. The soil in Shorter was a Lynchburg loamy sand (fine-loamy, siliceous, semiactive, thermic Aeric Paleaquults) and at Fairhope was a Malbis fine sandy loam (fine-loamy, siliceous, subactive, thermic Plinthic Paleudults). In April 2010, the experiment was again established at Fairhope, AL (Fairhope 2010) and in June 2010 at the USDA-ARS Dale Bumpers Small Farms Research Center in Booneville, AR (Booneville 2010; $\left.93^{\circ} 59^{\prime} 35^{\prime \prime} \mathrm{W}, 35^{\circ} 5^{\prime} 10^{\prime \prime} \mathrm{N}\right)$. The soil in Booneville was a Leadvale silt loam (fine-silty, siliceous, semiactive, thermic Typic Fragiudult).

The planting dates for each site-year are as follows: EVS, April 30, 2009; Fairhope, April 8, 2009 and May 5, 2010; Booneville, June 3,2010 . All locations are positioned in the mid-south region of the U.S. and have temperate climates. To more fully characterize each site-year the average maximum temperature $\left(T_{\max }\right)$, minimum temperature $\left(T_{\min }\right)$, and rainfall $(\mathrm{mm})$ are reported in Table 1. Because 7 years of climate data were available for all locations, the 7 year mean for each of the aforementioned climatic variables is also reported for each site-year (Table 1).

A photoperiod-sensitive variety of sorghum (variety 1990) was obtained from Sorghum Partners, Inc. (New Deal, TX) and sown in plots according to the row spacings and seeding rates described in Section 2.2. Variety 1990 is a late maturing, tall silage hybrid (Sorghum Partners, 2009) and produces a head only when there is less than $12 \mathrm{~h}$ and $20 \mathrm{~min}$ of daylight. Consequently, this variety would be expected to continue vegetative growth through most of the growing season and to produce high biomass yields at all locations utilized in this study.

At planting, $56.0 \mathrm{~kg} \mathrm{Nha}^{-1}$ was applied and an additional $78.5 \mathrm{~kg} \mathrm{Nha}^{-1}$ was side dressed later in the spring for a total of $134.5 \mathrm{~kg} \mathrm{~N} \mathrm{ha}^{-1}$ on all plots. Soil test recommendations were used for the application of $\mathrm{P}$ and $\mathrm{K}$. All other soil fertility and pest control were managed using Auburn University extension recommendations previously developed for forage sorghum. At the Booneville location, an additional $22.4 \mathrm{~kg} \mathrm{~N} \mathrm{ha}^{-1}$ was applied at planting due to soil requirements.

\subsection{Seeding rate and row spacing treatments}

Three seeding rates were used for the experiment: low (8.41 kg ha ${ }^{-1}$ for EVS 2009 and $4.48 \mathrm{~kg} \mathrm{ha}^{-1}$ for all other siteyears), medium ( $11.77 \mathrm{~kg} \mathrm{ha}^{-1}$ for EVS 2009 and $7.85 \mathrm{~kg} \mathrm{ha}^{-1}$ for all other site years), and high $\left(15.13 \mathrm{~kg} \mathrm{ha}^{-1}\right.$ for EVS 2009 and $11.21 \mathrm{~kg} \mathrm{ha}^{-1}$ for all other site-years) seeding rates. The number of seed per $\mathrm{kg}$ were determined, and seeding rates were subsequently expressed as seed $\mathrm{ha}^{-1}$ as follows: low $\left(218,000\right.$ seeds ha $^{-1}$ for EVS 2009 and 116,000 seeds ha ${ }^{-1}$ for all other site-years), medium (306,000 seeds ha ${ }^{-1}$ for EVS 2009 and 204,000 seeds ha ${ }^{-1}$ for all other site years), and high (393,000 seeds ha ${ }^{-1}$ for EVS 2009 and 291,000 seeds ha $^{-1}$ for all other site-years). Three row spacings were used in the experiment: $76 \mathrm{~cm}, 38 \mathrm{~cm}$, and $19 \mathrm{~cm}$ (drilled), and all plots were directly seeded. Various planting equipment was used at all locations to obtain the multiple row spacings. In 2009 at Auburn and Fairhope, the $19 \mathrm{~cm}$ row spacings (drilled) were obtained with a Marliss $3.0 \mathrm{~m}$ grain drill (Sukup Manufacturing Company, Sheffield, IA). The wider row spacings of 38 and $76 \mathrm{~cm}$ were obtained with a Kinze 6-row planter (Kinze Manufacturing, Inc., Williamsburg, IA) which was set on $76 \mathrm{~cm}$ row spacing. To obtain the $38 \mathrm{~cm}$ row spacing, the planter was operated a second pass in the previous row middles.

In 2010, a John Deere $159010 \mathrm{ft}$ no-till drill (Deere and Co., Moline, IL) was used in Fairhope to obtain all 3 row spacings. Holes in the drill were covered with tape to only allow seeds to come out at the various row spacings. At Booneville in 2010, a Marliss $3.0 \mathrm{~m}$ grain drill was again used for the $19 \mathrm{~cm}$ row spacing. The wider row spacings were obtained with an experimental AGCO row planter (AGCO Corporation, Duluth, GA) that had individual units that could be turned on or off as needed to obtain both the 38 and $76 \mathrm{~cm}$ row spacing. Plant emergence was good across all site-years.

The experimental design for each site-year was a completely randomized design with two independent variables (row spacing

Table 1

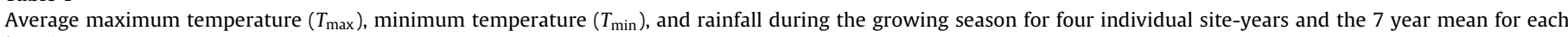
location.

\begin{tabular}{|c|c|c|c|c|c|c|}
\hline Site-year & $T_{\max }$ & $T_{\max }(7$ year $)$ & $T_{\min }$ & $T_{\min }(7$ year $)$ & Rainfall & Rainfall (7 year) \\
\hline EVS 2009 & $28.7^{\circ} \mathrm{C}$ & $29.3^{\circ} \mathrm{C}$ & $19.2^{\circ} \mathrm{C}$ & $18.8^{\circ} \mathrm{C}$ & $805 \mathrm{~mm}$ & $598 \mathrm{~mm}$ \\
\hline Fairhope 2009 & $30.4^{\circ} \mathrm{C}$ & $30.0^{\circ} \mathrm{C}$ & $21.0^{\circ} \mathrm{C}$ & $20.0^{\circ} \mathrm{C}$ & $799 \mathrm{~mm}$ & $691 \mathrm{~mm}$ \\
\hline Fairhope 2010 & $31.9^{\circ} \mathrm{C}$ & $31.0^{\circ} \mathrm{C}$ & $22.5^{\circ} \mathrm{C}$ & $21.0^{\circ} \mathrm{C}$ & $693 \mathrm{~mm}$ & $686 \mathrm{~mm}$ \\
\hline Booneville 2010 & $33.0^{\circ} \mathrm{C}$ & $31.2^{\circ} \mathrm{C}$ & $17.5^{\circ} \mathrm{C}$ & $16.3^{\circ} \mathrm{C}$ & $324 \mathrm{~mm}$ & $487 \mathrm{~mm}$ \\
\hline
\end{tabular}


and seeding rate) and three levels of each independent variable: 76,38 , and $19 \mathrm{~cm}$ row spacing, and low, medium, and high seeding rate. A $3 \times 3$ factorial arrangement of treatments was utilized in this study, where there were three levels of each independent variable for a total of 9 treatments. The experiment was completely balanced: $n=4$ for each of the 9 possible treatments ( $n=12$ for row spacing and $n=12$ for seeding rate main effects).

\subsection{Harvesting and yield determination}

To obtain sorghum yield for each location, $1.5 \mathrm{~m}$ of two crop rows in the middle of each plot were harvested by hand on the following dates for each site-year: EVS, November 6, 2009; Fairhope, October 8, 2009 and October 6, 2010; Booneville, October 25 2010. Harvesting was conducted as soon as practically possible following killing frost. Bulk samples were weighed immediately following harvest. Subsamples were obtained from each harvested plot, weighed, dried for $24 \mathrm{~h}$ in an oven at $105^{\circ} \mathrm{C}$, and weighed again to correct for the moisture content of each sample. Aboveground dry biomass yields were expressed in $\mathrm{Mg} \mathrm{ha}^{-1}$. Although later harvest dates (October-November) were utilized throughout the majority of this study, an experiment was conducted at the Booneville 2010 site-year to determine the appropriate time to harvest for maximum biomass production. $1.5 \mathrm{~m}$ of two middle crop rows were harvested by hand at three different times during the growing season. These harvest times were scheduled in four-week intervals beginning in mid August (August 24, September 23, and
October 25). The final harvest date produced the highest aboveground biomass levels (results not shown), suggesting that the later harvest dates were most appropriate for maximum biomass production in this study.

\subsection{Plant height, stem density, and stem diameter measurements}

Stem density and plant height were determined for the EVS 2009, Fairhope 2010, and Booneville 2010 site-years. At harvest, stem density was estimated by measuring the number of stems in $1.5 \mathrm{~m}$ of two crop rows in the middle of each plot, and was expressed as stems ha ${ }^{-1}$. Plant height $(\mathrm{m})$ was measured on harvested stalks of 10 randomly selected plants in each plot. Stem diameter was measured for the Fairhope 2010 and Booneville 2010 site-years only. At harvest, stem diameter $(\mathrm{mm})$ was measured at the base of the harvested stalks of 10 randomly selected plants in each plot.

\subsection{Statistics}

For each site within a given year, the effect of row spacing and seeding rate on above-ground dry matter yield, plant height, plant population, and stem diameter were compared using a two-way ANOVA (2 factor full factorial analysis of variance), and means were separated via conventional LSD post hoc analysis $(\alpha=0.05)$. Statistical analyses were performed using JMP 9 software (SAS Institute, Cary, NC, USA).
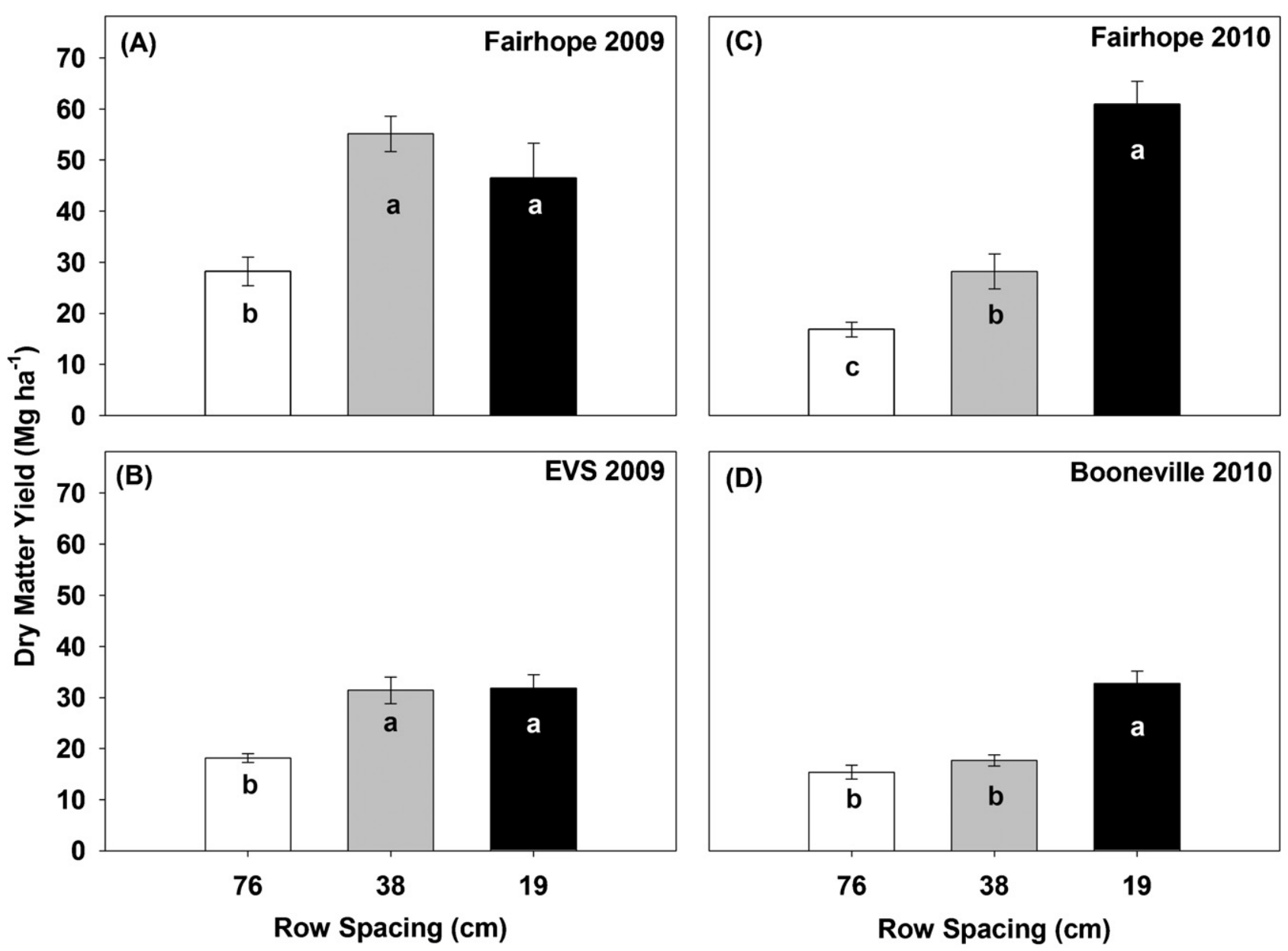

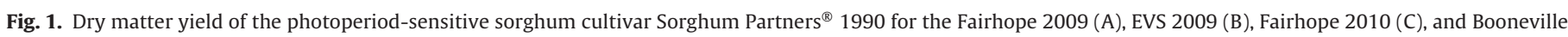

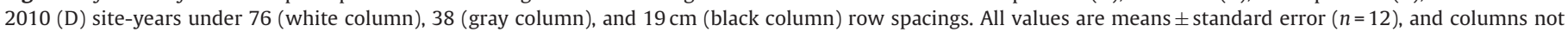
sharing a common letter are significantly different (LSD; $P<0.05$ ). 


\section{Results}

\subsection{Yield}

Dry matter yield in photoperiod-sensitive sorghum was significantly affected by row spacing in all studies (Fig. $1 ; P \leq 0.0020$, $0.0001,0.0001$, and 0.0001 for Fairhope 2009, EVS 2009, Fairhope 2010, and Booneville 2010, respectively). In 2009, comparable yield trends were observed for Fairhope (Fairhope 2009; Fig. 1A) and near Auburn, AL (EVS 2009; Fig. 1B). For both sites that year biomass production was significantly lower under the $76 \mathrm{~cm}$ row spacing than under the 38 or $19 \mathrm{~cm}$ row spacing, which were not statistically different. In 2010, biomass yields at Fairhope increased with narrow row spacing with the maximum yield observed under the $19 \mathrm{~cm}$ row spacing $\left(61.13 \mathrm{Mg} \mathrm{ha}^{-1}\right.$; Fig. 1C). At the study site near Booneville, AR in 2010, yields were similar under the 76 (15.43 $\mathrm{Mg} \mathrm{ha}^{-1}$ ) and $38\left(17.71 \mathrm{Mg} \mathrm{ha}^{-1}\right) \mathrm{cm}$ row spacing, but were significantly higher under the $19 \mathrm{~cm}\left(32.89 \mathrm{Mg} \mathrm{ha}^{-1}\right)$ row spacing (Fig. 1D).

Increasing seeding rate usually had no significant effect on yield (Fig. 2). At the one site where there were significant differences (EVS 2009), increasing seeding rate significantly decreased yield for the highest rate compared to the lowest. Yields were statistically indistinguishable at all seeding rates for Fairhope 2009 (Fig. 2A; $P=0.21$ ), Fairhope 2010 (Fig. 2C; $P=0.19$ ), and Booneville 2010 (Fig. 2D; $P=0.85$ ). For EVS 2009, biomass yields were significantly affected by seeding rate (Fig. $2 \mathrm{~B} ; P=0.035)$, where yields at the low seeding rate were significantly higher $(31.07 \mathrm{Mg})$ than yields observed at the high seeding rate of (23.12 $\left.\mathrm{Mg} \mathrm{ha}^{-1}\right)$.

\subsection{Plant height and stem density}

Plant height was unaffected by row spacing in all studies for which plant height data were available (Fig. 3A-C; $P=0.93,0.16$, and 0.50 for EVS 2009, Fairhope 2010, and Booneville 2010). In contrast, stem density was strongly affected by row spacing (Fig. 3D-F) when data were pooled across all seeding rates. For EVS 2009, stem density was significantly lower at the $76 \mathrm{~cm}$ row spacing $\left(205,000\right.$ stems ha $\left.^{-1}\right)$ than either the $38 \mathrm{~cm}\left(340,000\right.$ stems ha $\left.^{-1}\right)$ or $19 \mathrm{~cm}\left(387,000\right.$ stems ha $\left.^{-1}\right)$ row spacings, which were statistically the same (Fig. 3D; $P<0.0001$ ). For Fairhope 2010 (Fig. 3E; $P<0.0001$ ) and Booneville 2010 (Fig. 3F; $P<0.0001$ ) stem density increased with successively narrower row spacing. The maximum stem densities were observed at the $19 \mathrm{~cm}$ row spacing for both locations and were 195,000 and 291,000 stems ha $^{-1}$ for Fairhope and Booneville, respectively.

Seeding rate affected plant height in two of the three site-years measured, but in opposite directions (EVS 2009; Fig. 4A; $P=0.005$ and Fairhope 2010; Fig. 4B; $P=0.017$ ). For example, plant height declined with seeding rate and was significantly lower at the high seeding rate than at the low seeding rate for EVS 2009 (Fig. 4A). For Fairhope 2010 plant height increased with higher seeding rates,
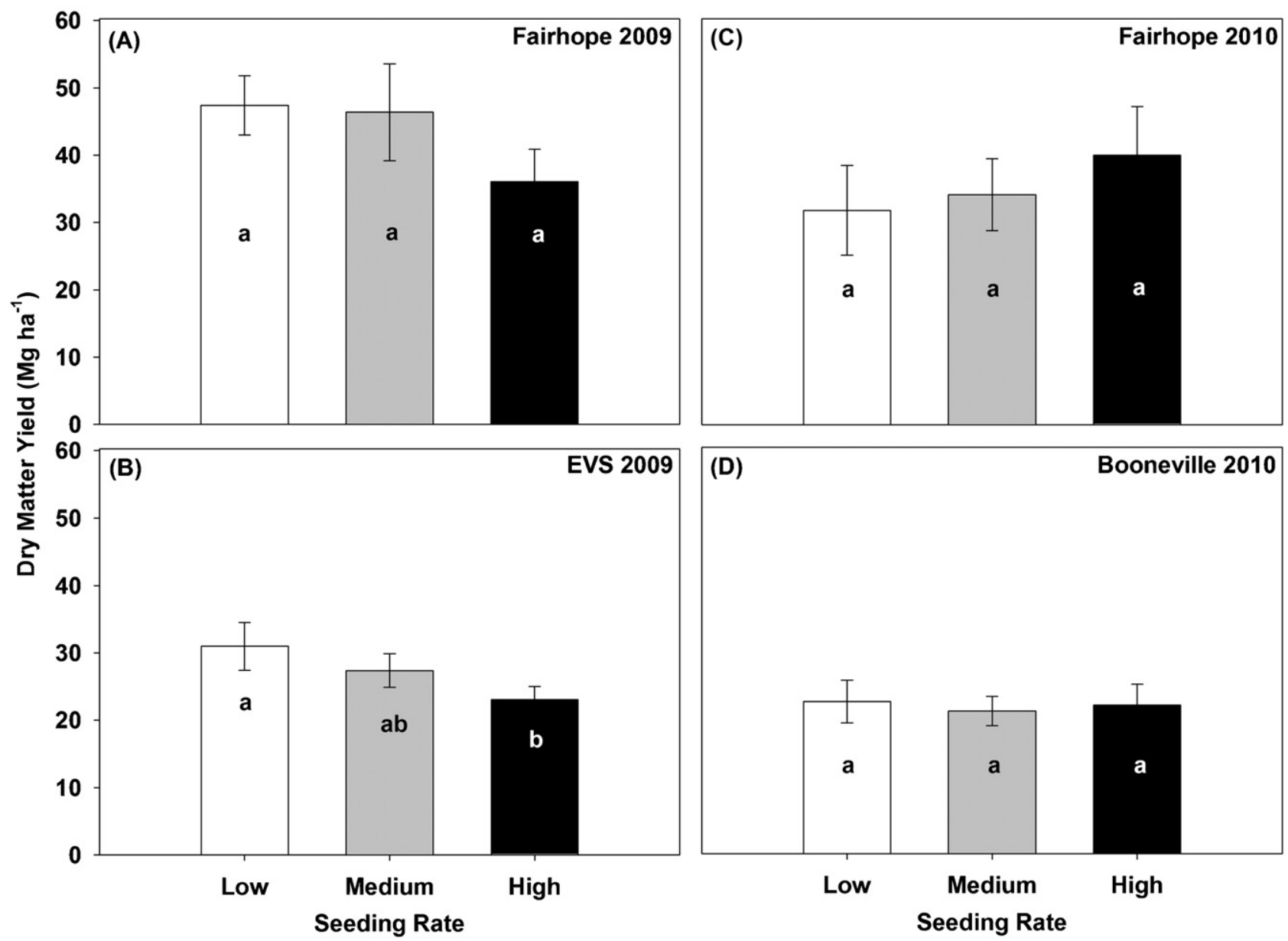

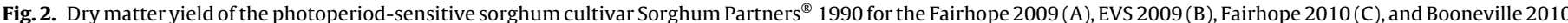

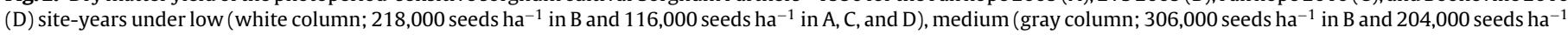

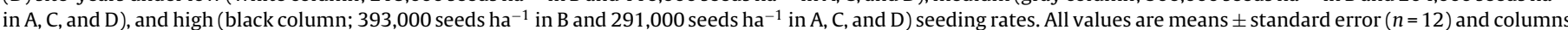
not sharing a common letter are significantly different (LSD; $P<0.05$ ). 

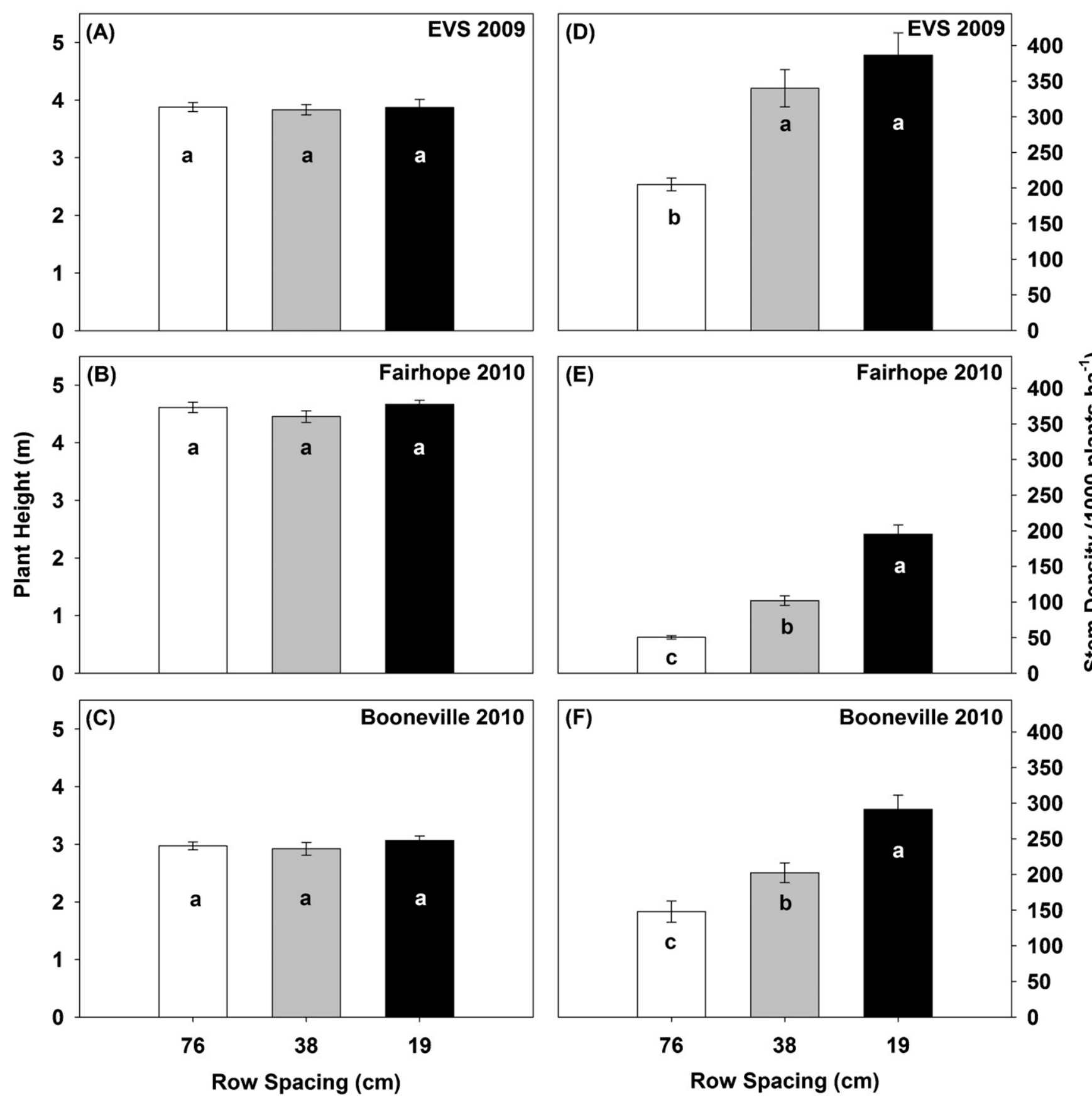

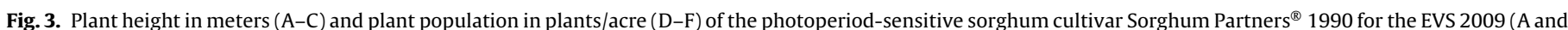

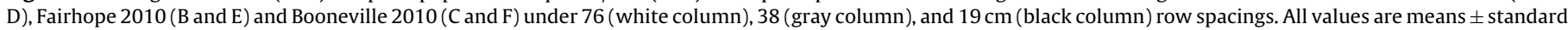
error $(n=12)$, and columns not sharing a common letter are significantly different (LSD; $P<0.05)$.

where plants were significantly taller at the high seeding rate than at the low seeding rate (Fig. $4 \mathrm{~B} ; P=0.017$ ). At Booneville, plant height did not differ significantly across all seeding rates (Fig. 4C; $P=0.38$ )

Seeding rate did not influence stem density at two of the three site-years mentioned. At the Alabama study sites seeding rate did not significantly affect stem density (Fig. $4 \mathrm{~A}$ and $\mathrm{B} ; P=0.053$ and 0.58 for EVS 2009 and Fairhope 2010). However, stem density responded positively to increased seeding rate at the study site near Booneville, AR (Fig. 4C; $P=0.017$ ). Stem density increased significantly from the low seeding rate $\left(182,000\right.$ stems ha $\left.^{-1}\right)$ to the medium seeding rate $\left(233,000\right.$ stems ha $\left.^{-1}\right)$ and stem density at the high seeding rate $\left(227,000\right.$ stems ha $\left.^{-1}\right)$ was not statistically different from that observed at the medium seeding rate (Fig. 4C).

\subsection{Stem diameter}

Row spacing did not significantly affect stem diameter at Fairhope (Fig. 5A; $P=0.8145$ ) or Booneville (Fig. $5 B ; P=0.18$ ) in 2010 , where stem diameter was similar at all row spacings. Stem diameter was also unresponsive to seeding rate at the Fairhope 

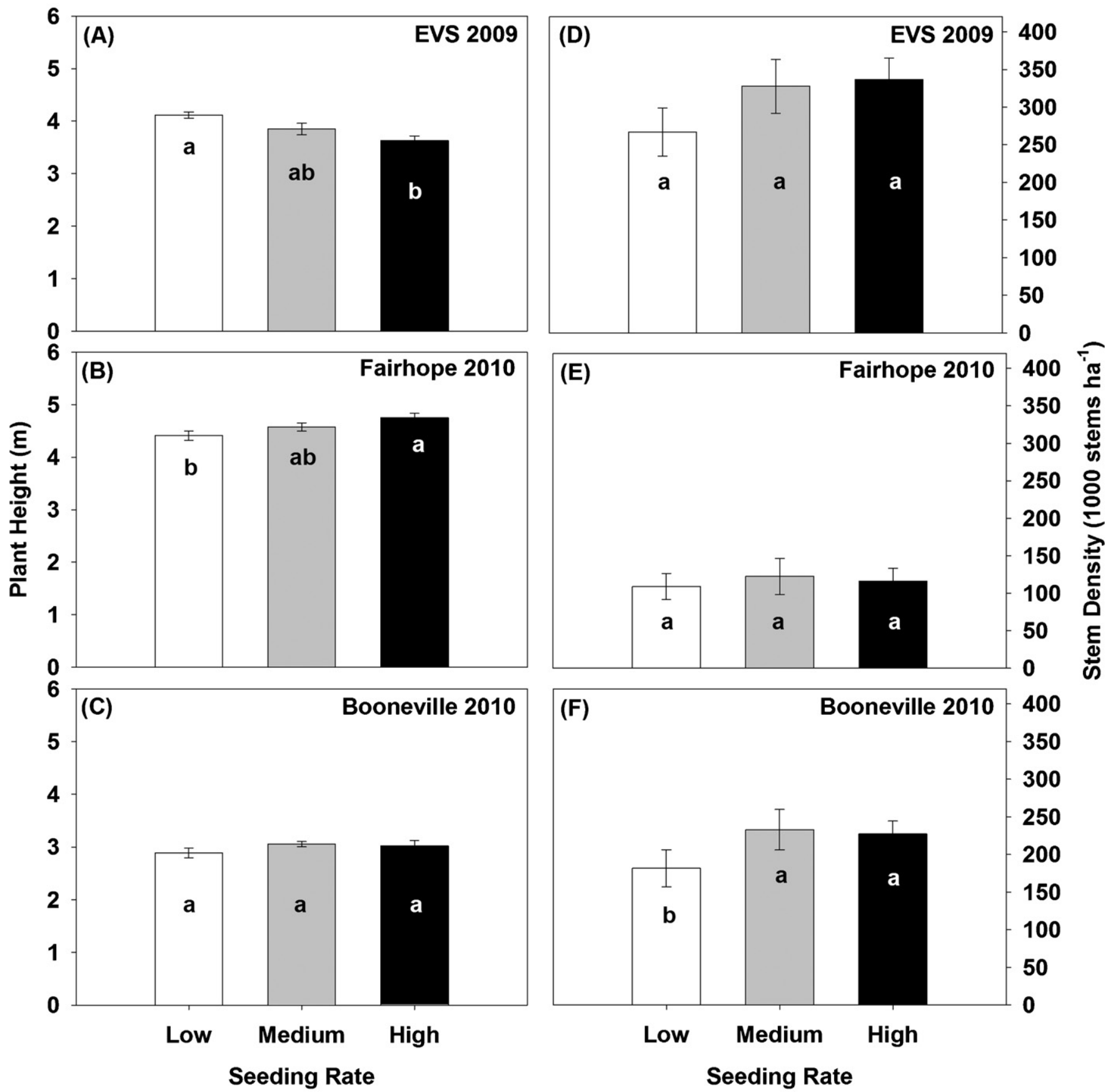

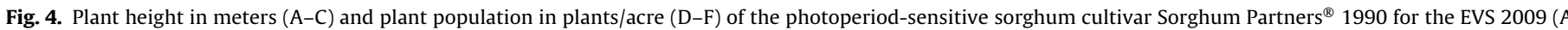

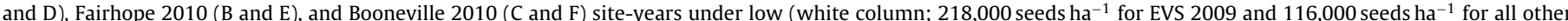

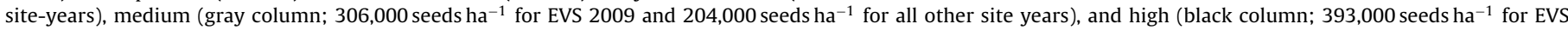

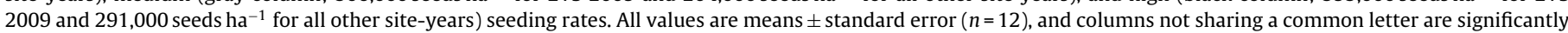
different (LSD; $P<0.05$ ).

location (Fig. 5C; $P=0.13$ ). At Booneville in 2010, the low seeding rate resulted in plants having larger stem diameters $(17.79 \mathrm{~mm})$ than under the medium $(16.02 \mathrm{~mm})$ and high $(16.07 \mathrm{~mm})$ seeding rates, which produced statistically comparable stem diameters (Fig. 5D; $P=0.045$ ).

\subsection{Seeding rate and row spacing interaction for Booneville 2010}

Although interactions between seeding rate and row spacing were not observed for the other site-years, at the Booneville location in 2010 there was a significant interaction between seeding rate and row spacing for stem density (Fig. 6 ; $P=0.0092$ ). For example, stem density increased with increasing seeding rate under the 76 and $38 \mathrm{~cm}$ row spacing and was greatest at the high seeding rate. Under the $19 \mathrm{~cm}$ row spacing, stem density initially increased from 263,000 stems ha-1 at the low seeding rate to a maximum of 353,000 stems ha $^{-1}$ at the medium seeding rate then declined to 258,000 stems ha $^{-1}$ at the high seeding rate. The $19 \mathrm{~cm}$ row spacing produced significantly higher stem densities than the $38 \mathrm{~cm}$ row spacings under both the low and medium seeding rates, and significantly higher stem densities than the $76 \mathrm{~cm}$ row spacing at all seeding rates (Fig. 6). 

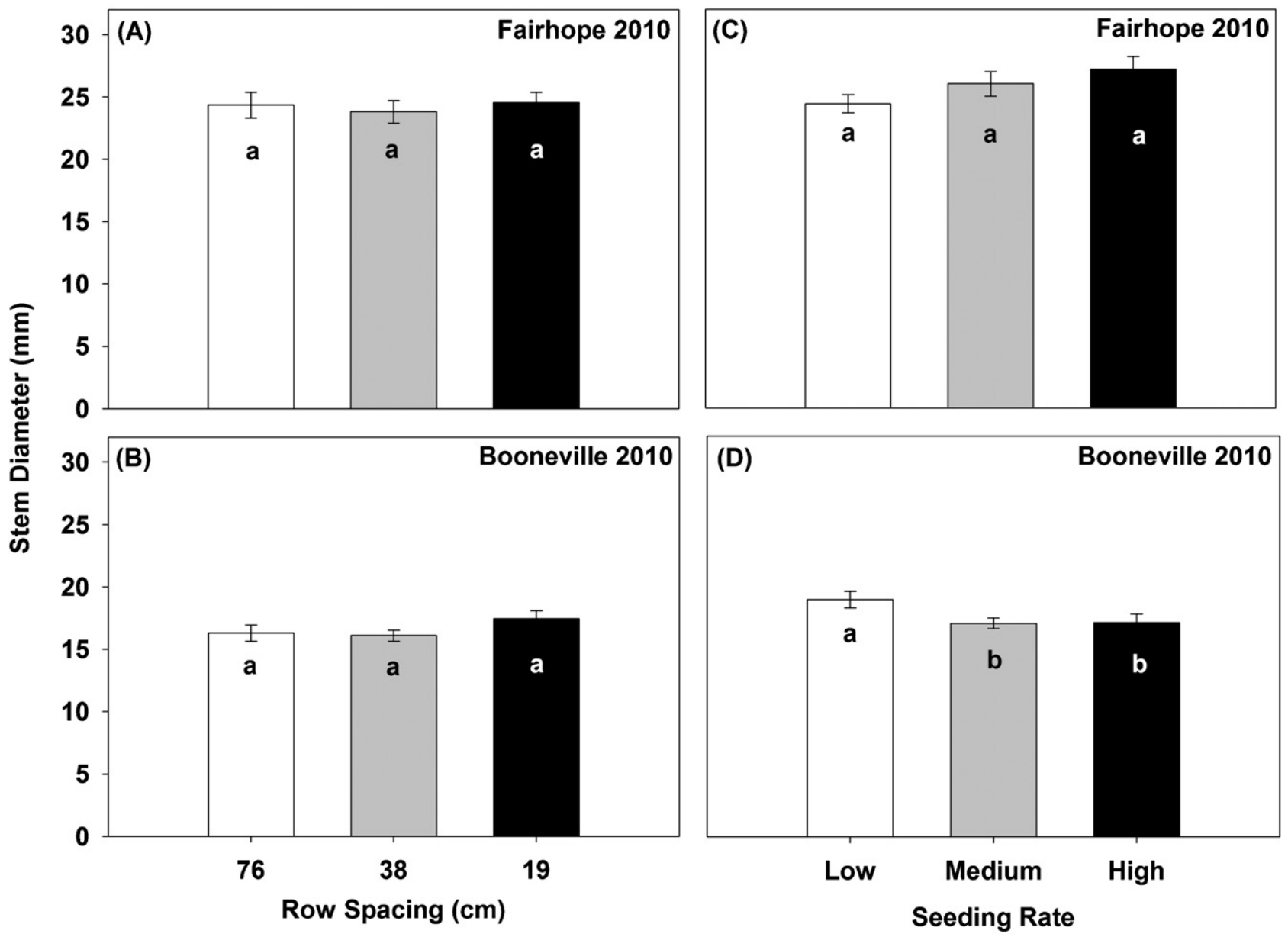

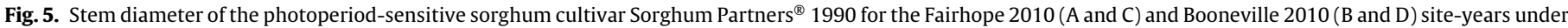

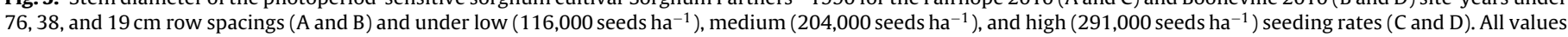
are means \pm standard error $(n=12)$, and columns not sharing a common letter are significantly different (LSD; $P<0.05)$.

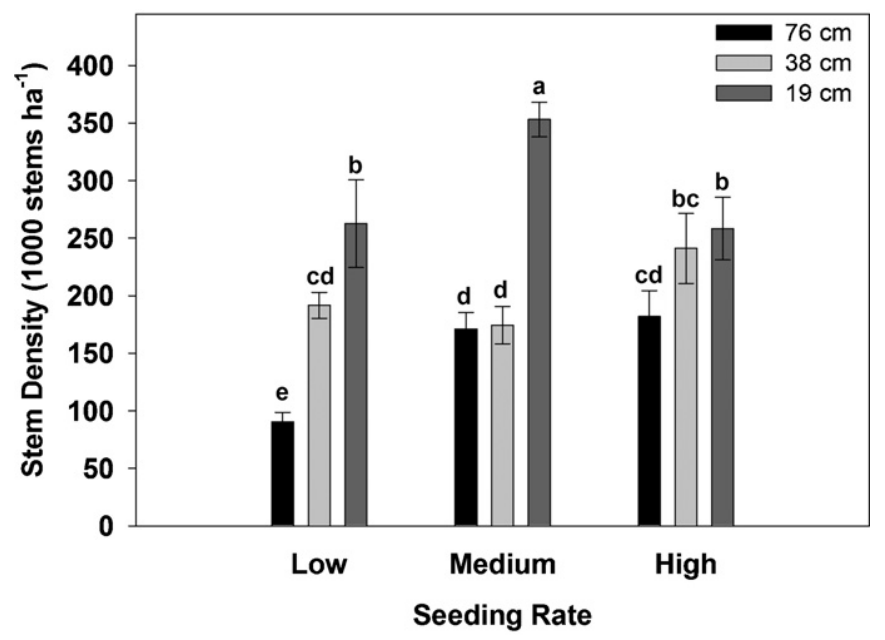

Fig. 6. The interactive effects of seeding rate and row spacing on plant population (plants ha ${ }^{-1}$ ) for Sorghum Partners ${ }^{\circledR} 1990$ for the Booneville 2010 site-year. All values are means \pm standard error $(n=4)$, and columns not sharing a common letter are significantly different (LSD; $P<0.05$ ).

\section{Discussion}

Narrower row spacing positively impacted yield for all locations and years studied. For example, during 2009 the 38 and $19 \mathrm{~cm}$ row spacings produced similar yields that were significantly higher than for sorghum grown under the $76 \mathrm{~cm}$ row spacing. In 2010, above-grown biomass yields continued to improve with narrower row spacing and were maximal under a $19 \mathrm{~cm}$ row spacing for the Booneville and Fairhope locations. Similar responses to row spacing have been observed previously, where narrower row spacing favors higher yields in both grain (Stickler and Laude, 1960; Steiner, 1986) and forage sorghum (Stickler and Laude, 1960) among other crop species (i.e. soybean; De Bruin and Pedersen 2008). Higher yields at narrower row spacings could be explained by improved light interception (Steiner, 1986) and decreased intra-row competition between plants (De Bruin and Pederson, 2008).

In contrast, increasing seeding rate from 218,000 to 393 seeds ha ${ }^{-1}$ for the EVS 2009 site-year significantly decreased yield, but seeding rates ranging from 116,000 to 291,000 seeds ha ${ }^{-1}$ at all other locations did not significantly impact yields. Reports on the effect of seeding rate on yield in sorghum have been inconsistent, where higher seeding rates have been shown to increase dry matter productivity in some instances, and to have no effect on yield in others (Stickler and Laude, 1960; Steiner, 1986; Habyarimana et al., 2004; Wortmann et al., 2010). Sorghum yield responses to seeding rate appear to be dependent upon location and cultivar (Habyarimana et al., 2004; Wortmann et al., 2010). Therefore, based upon the above-ground biomass production data, the $19 \mathrm{~cm}$ row spacing and 116,000 seeds ha ${ }^{-1}$ seeding rate would be expected to produce the highest above-ground biomass levels 
with the lowest seed input for the photoperiod-sensitive sorghum cultivar utilized in this study.

Final stem density at harvest was positively affected by narrower row spacing at all locations. These findings suggest that plant stand establishment may be more favorable under narrower row spacing, despite average seeding rates being the same for all row spacings. A likely explanation for poorer stand establishment under wider row spacings (i.e. $76 \mathrm{~cm}$ row spacing) is that wider rows would receive a greater number of seed per length of row, thereby increasing intra-row competition between plants during early stand establishment. Similar declines in plant population with increased row spacing have been observed for other crop species (De Bruin and Pedersen 2008), where intra-row competition between plants has been cited as the likely cause of lower plant populations at wide row spacings.

Higher seeding rates inconsistently affected stem density in photoperiod-sensitive sorghum. Increases in plant population with increased seeding rate were only observed at the Booneville location, but at both Alabama sites, seeding rate did not affect plant population. Other authors have observed increases in plant population with increased seeding rates (Faris and De Pauw, 1980; Steiner, 1986; Geleta et al., 2002; Habyarimana et al., 2004; Wortmann et al., 2010), as observed near Booneville. However, it is important to note that the highest seeding rates evaluated by other authors ( $\leq 200,000$ viable seed $\mathrm{ha}^{-1}$; Steiner, 1986; Habyarimana et al., 2004; Wortmann et al., 2010) would produce substantially lower plant populations than the stem densities observed in the present study $\left(\leq 336,783\right.$ stems ha $^{-1}$ ). Consequently, interplant competition could be more pronounced at the higher seeding rates, which causes self-thinning in some species (Van Der Werf et al., 1995). However, for EVS 2009 and Booneville 2010 under the low seeding rate, stem density was higher than the number of seeds sown, suggesting that tillering also occurred in this variety. Increased tiller production under low plant densities has been observed previously in grain sorghum (Gerik and Neely, 1987); therefore, we suggest that plant compensation via tillering may maintain stem density in some instances.

Row spacing had no effect on plant height, or stem diameter. Consequently, there does not appear to be a well defined response of plant height or stem diameter to row spacing for the cultivar and locations utilized in this study. In contrast, seeding rate significantly affected plant height for the EVS 2009 and Fairhope 2010 site-years. For EVS 2009, plant height declined with increasing seeding rate, and for Fairhope 2010 plant height increased with increasing seeding rate. An important difference between the two locations is that the seeding rates and stem densities were substantially higher for the EVS-2009 site-year than either of the other site-years. Higher plant densities can sometimes stimulate increases in plant height (similar to the trend observed for Fairhope 2010) due to internode elongation (Schmitt and Wulff, 1993). However, plant height has also been shown to decline with excessively high plant densities (Van Der Werf et al., 1995) as observed for the EVS 2009 site-year.

Stem diameter was unaffected by seeding rate at the Fairhope 2010 site-year and declined significantly at seeding rates in excess of 116,000 seeds ha ${ }^{-1}$ for Booneville 2010. Stem diameter declined concomitantly with increasing stem density in response to higher seeding rates at the Booneville location, and we suggest that higher stem densities observed with increasing seeding rates caused a concomitant decline in stem diameter as a response to interplant competition (Schmitt and Wulff, 1993; Van Der Werf et al., 1995). Because tall plants with thin stems would be expected to be more susceptible to lodging (Wilcox and Sediyama, 1981; Kashiwagi et al., 2008; Venuto and Kindiger, 2008), high seeding rates should be avoided for photoperiod-sensitive sorghum in regions where lodging is a major concern.

\section{Conclusion}

Above-ground dry biomass production in photoperiod-sensitive sorghum was maximal for all site-years at the narrowest row spacing utilized in this study $(19 \mathrm{~cm})$. Increasing seeding rate from 116,000 to 291,000 seeds ha $^{-1}$ did not affect yield for three of the site-years, but increasing seeding rate from 218,000 to 393,000 seeds ha $^{-1}$ for the EVS 2009 site-year significantly decreased yield. Row spacing primarily influenced stem density, where the $19 \mathrm{~cm}$ row spacing produced the highest stem densities for all site-years. Plant height was primarily affected by seeding rate, where plant height increased with seeding rates ranging from 116,000 to 291,000 seeds ha ${ }^{-1}$ at one site and decreased with seeding rates ranging from 218,000 to 393,000 seeds ha $^{-1}$ at another site. At one location, stem diameter declined as seeding rates increased from 116,000 to 291,000 seeds ha ${ }^{-1}$. It is concluded that the $19 \mathrm{~cm}$ row spacing provides the maximum yield benefit by significantly increasing stem density. Because seeding rates higher than 116,000 seeds ha ${ }^{-1}$ had either no effect on biomass production or significantly decreased productivity in addition to causing morphological changes conducive to lodging (i.e. thinner stems and taller plants), it is suggested that a seeding rate of 116,000 seeds ha $^{-1}$ may provide optimal productivity with lower inputs.

\section{Acknowledgements}

The authors thank David Burner, Tammy Horton, Karl Mannschreck, Jarrod Jones, Morris Welch, Gogo Jones, Danny Henson, David Miller, and Larry Huddleston for their support with this project. Mention of trade names or commercial products in this publication is solely for the purpose of providing specific information and does not imply recommendation or endorsement by the U.S. Department of Agriculture. USDA is an equal opportunity provider and employer.

\section{References}

Amaducci, S., Amaducci, M.T., Benati, R., Venturi, G., 2000. Crop yield and quality parameters of four annual fibre crops (hemp, kenaf, maize and sorghum) in the north of Italy. Ind. Crops Prod. 11, 179-186.

Aylott, M.J., Casella, E., Tubby, I., Street, N.R., Smith, P., Taylor, G., 2008. Yield and spatial supply of bioenergy poplar and willow short-rotation coppice in the UK. New Phytol. 178, 358-370.

Ball, D.M., 1998. Summer Annual Grasses as Forage Crops in Alabama. Alabama Cooperative Extension System, ANR-134.

Carpita, N.C., McCann, M.C., 2008. Maize and sorghum: genetic resources for bioenergy grasses. Trends Plant Sci. 13, 415-420.

De Bruin, J.L., Pederson, P., 2008. Effect of row spacing and seeding rate on soybean yield. Agron. J. 100, 704-710.

Faris, D.G., De Pauw, R.M., 1980. Effect of seeding rate on growth and yield of three spring wheat cultivars. Field Crops Res. 3, 289-301.

Fischer, G., Prieler, S., van Velthuisan, H., 2005. Biomass potentials of Micanthus, willow and poplar: results and policy implications for Eastern Europe, Northern and Central Asia. Biomass Bioenergy 28, 119-132.

Geleta, B., Atak, M., Baenziger, P.S., Nelson, L.A., Baltenesperger, D.D., Eskridge, K.M. Shipman, M.J., Shelton, D.R., 2002. Seeding rate and genotype effect on agronomic performance and end-use quality of winter wheat. Crop Sci. 42, 827-832.

Gerik, T.J., Neely, C.L., 1987. Plant density effects on main culm and tiller development of grain sorghum. Crop Sci. 27, 1225-1230.

Habyarimana, E., Bonardi, P., Laureti, D., Di Bari, V., Cosentino, S., Lorenzoni, C., 2004. Multilocational evaluation of biomass sorghum hybrids under two stand densities and variable water supply in Italy. Ind. Crops Prod. 20, 3-9.

Kashiwagi, T., Togawa, E., Hirotsu, N., Ishimaru, K., 2008. Improvement of lodging resistance with QTLs for stem diameter in rice (Oryza sativa L.). Theor. Appl. Genet. 117, 749-757.

Marsalis, M.A., Angadi, S.V., Contreras-Govea, F.E., 2010. Dry matter yield and nutritive value of corn, forage sorghum, and BMR forage sorghum at different plant populations and nitrogen rates. Field Crops Res. 116, 52-57.

Martin, P.M., Kelleher, F.M., 1984. Effects of row spacing and plant population on sweet sorghum yield. Aust. J. Exp. Agric. Anim. Husb. 24, 386-390.

Mask, P.L., Hagan, A., Mitchell Jr., C.C., 1988. Production Guide for Grain Sorghum. Alabama Cooperative Extension System, ANR-502. 
Mask, P.L., Morris, W.C., 1991. Sweet Sorghum Culture and Syrup Production. Alabama Cooperative Extension System, ANR-625.

Rooney, W.L., Blumenthal, J., Bean, B., Mullet, J.E., 2007. Designing sorghum as a dedicated bioenergy feedstock. Biofuels Bioprod. Bioref. 1, 147-157.

Schmer, M.R., Vogel, K.P., Mitchell, R.B., Perrin, R.K., 2008. Net energy of cellulosic ethanol from switchgrass. Proc. Natl. Acad. Sci. USA 105, 464-469.

Schmitt, J., Wulff, R.D., 1993. Light spectral quality, phytochrome and plant competition. Trends Ecol. Evol. 8, 47-51.

Service, R.F., 2010. Is there a road ahead for cellulosic ethanol? Science 329, 784-785.

Sivakumar, G., Vail, D.R., Xu, J., Burner, D.M., Lay Jr., J.O., Ge, X., Weathers, P.J., 2010. Bioethanol and biodiesel: alternative liquid fuels for future generations. Eng. Life Sci. 10, 8-18.

Sorghum Partners Inc., 2009. 1990 Hybrid Forage Sorghum Technical Information, 2 pp., http://www.sorghum-partners.com/tech/199.pdf (retrieved 02.05.11).

Steiner, J.L., 1986. Dryland grain sorghum water use, light interception, and growth responses to planting geometry. Agron. J. 78, 720-726.

Stickler, F.C., Laude, H.H., 1960. Effect of row spacing and plant population on performance of corn, grain sorghum and forage sorghum. Agron. J. 52, 275-277.
Stolarski, M.J., Szcukowski, S., Tworkowski, J., Wroblewska, H., Krzyzaniak, M., 2011. Short rotation willow coppice biomass as an industrial and energy feedstock. Ind. Crops Prod. 33, 217-223.

Van Der Werf, H.M.G., Wijlhuizen, M., de Schutter, J.A.A., 1995. Planting density and self thinning affect yield and quality of fibre hemp (Cannabis sativa L.). Field Crops Res. 40, 153-164.

Venuto, B., Kindiger, B., 2008. Forage and biomass feedstock production from hybrid forage sorghum and sorghum-sudangrass hybrids. Grassl. Sci. 54, 189- 196.

Waltz, E., 2008. Cellulosic ethanol booms despite unproven business models. Nat. Biotechnol. 26, 8-9.

Wang, D., Bean, S., McLaren, J., Seib, P., Madl, R., Tuinstra, M., Shi, Y., Lenz, M., Wu, X., Zhao, R., 2008. Grain sorghum is a viable feedstock for ethanol production. J. Ind. Microbiol. Biotechnol. 35, 313-320.

Wilcox, J.R., Sediyama, T., 1981. Interrelationships among height, lodging and yield in determinate and indeterminate soybeans. Euphytica 30, 323-326.

Wortmann, C.S., Liska, A.J., Ferguson, R.B., Lyon, D.J., Klein, R.N., Dweikat, I., 2010. Dryland performance of sweet sorghum and grain crops for biofuel in Nebraska. Agron. J. 102, 319-326.

Welch, N.H., Burnett, E., Eck, H.V., 1966. Effect of row spacing, plant population, and nitrogen fertilization on dryland grain sorghum production. Agron. J. 58, 160-163. 